\title{
The effect of 4-hexylresorinol administration on NAD+ level and SIRT activity in Saos-2 cells
}

\author{
In-Song Lee ${ }^{1 \dagger}$, Jun-Ho Chang ${ }^{1 \dagger}$, Dae-Won Kim², Seong-Gon Kim ${ }^{3^{*}}$ (D) and Tae-Woo Kim ${ }^{1^{*}}$
}

\begin{abstract}
Background: 4-hexylresorcinol (4HR) has been shown to have anti-oxidant activity similar to that of resveratrol. As resveratrol increases sirtuin (SIRT) activity, 4HR might behave similarly to resveratrol.

Method: In this study, the expression levels of SIRT1, SIRT3, and SIRT6 were evaluated after 4HR administration (1$100 \mu \mathrm{M})$. As NAD+ is a substrate for SIRTs, its levels with SIRT activity were also studied.

Results: In the results, SIRT3 (100 $\mu \mathrm{M}$ at $24 \mathrm{~h})$ and SIRT6 (1-100 $\mu \mathrm{M}$ at $24 \mathrm{~h}$ and $10 \mu \mathrm{M}$ at $8 \mathrm{~h}$ ) were shown to have significantly higher expression levels compared to untreated control $(p<0.05)$. Pan-SIRT activity and the NAD+ level was significantly increased compared to that of the untreated control ( $p<0.05 ; 10$ and $100 \mu \mathrm{M}$ at $24 \mathrm{~h}$ ).

Conclusion: 4HR administration increased SIRT activity and the NAD+ level in Saos-2 cells.

Keywords: 4-hexylresorcinol, Sirtuin, NAD+
\end{abstract}

\section{Background}

Most clinicians expect successful treatment outcomes after their practice. However, various dental procedures such as oral surgery and orthodontic tooth movement can apply stress to the teeth and surrounding dental tissue including alveolar bone. If tissue fails to manage the stress from surgical treatment, wound healing will be delayed and result in inflammation [1,2]. Although it is a rare incident, it also has been reported that pulpal side effects and root resorption can occur secondary to the orthodontic tooth movement [3]. Excessive stress is known to increases the production of reactive oxygen species (ROS) which is a main reason of inflammation [4-6]. Therefore, the application of anti-oxidant may be

\footnotetext{
* Correspondence: kimsg@gwnu.ac.kr; taewoo@snu.ac.kr

${ }^{+}$In-Song Lee and Jun-Ho Chang contributed equally.

${ }^{3}$ Department of Oral and Maxillofacial Surgery, College of Dentistry,

Gangneung-Wonju National University, Jibyun-dong, Gangneung,

Gangwondo 28644, Republic of Korea

'Department of Orthodontics, School of Dentistry, Seoul National University,

Seoul 3080, Republic of Korea

Full list of author information is available at the end of the article
}

beneficial preventing the complications from surgical [5] or orthodontic treatment [3].

Resveratrol is a natural polyphenol and has antioxidant activity [7]. Similar to resveratrol, 4hexylresorcinol (4HR) is a phenolic compound, but synthetic [8]. However, other resorcinolic lipids can be found in micro-organisms and plants [8]. The antioxidant effect of $4 \mathrm{HR}$ has been confirmed in lymphocytes [4], macrophages [5], and dental pulp cells [6]. When compared to resveratrol, the anti-oxidant activity of 4HR has a similar performance [4-6].

Anti-oxidant activity is associated with scavenging ROS from cells [4]. Sirtuins (SIRTs) are class III histone deacetylase, and their activity is related to relieving cellular stress and extending the lifespan [9]. Mammals have seven isoforms of SIRT (SIRT1 to 7). SIRTs are mainly found in the nucleus and mitochondria [9]. Specifically, SIRT3 is usually found in the mitochondrial compartment, but SIRT 1 and SIRT6 are in the nucleus [10]. Though there have been some conflicting results, resveratrol increases SIRT expression and activity [11]. 4HR has a chemical chaperone feature $[8,12]$. The 
administration of $4 \mathrm{HR}$ on micro-organisms induces a dormancy-like status [12]. Micro-organisms undergoing a dormancy state are much more resistant to the outer environment and can extend their lifespan [12]. Based on these observations, 4HR administration might increase SIRT activity.

The objective of this study was to evaluate SIRTs' expression and their activity in Saos- 2 cells. First, the expression levels of SIRT1, 3, and 6 were evaluated after 4 HR ad-ministration (1-100 $\mu \mathrm{M})$. Second, pan-SIRT activity and SIRT1 activity were evaluated. As nicotinamide adenine dinucleotide+ $(\mathrm{NAD}+)$ is a substrate for SIRTs, its level and NAD+/NADH ratio were evaluated.

\section{Methods}

\section{Cell cultures}

Saos-2 cells were purchased from Korean cell line bank (Seoul, Republic of Korea). Cells were grown in 6-wells culture plates in a humidified $\mathrm{CO}_{2}$ incubator at $37{ }^{\circ} \mathrm{C}$. The medium was Roswell Park Memorial Institute 1640 (RPMI 1640) medium (ThermoFisher Scientific, Waltham, MA, USA) supplemented with $10 \%$ fetal bovine serum (FBS) and antibiotics (1\% penicillinstreptomycin).

\section{Western blot}

4HR was solubilized in $0.1 \%$ dimethyl sulfoxide. When Saos- 2 cells were grown to approximately $70 \%$ confluence, the cells were treated with 1,10 , and $100 \mu \mathrm{M} 4 \mathrm{HR}$ for 2,8 , or $24 \mathrm{~h}$; control cells were treated with $0.1 \% \mathrm{di}$ methyl sulfoxide in culture medium. Cultured cells were harvested with $0.01 \%$ trypsin and $1 \mathrm{mM}$ ethylenediamine-tetra-acetic acid. Cellular lysis was carried out with protein lysis buffer (PRO-PREPTM, iNtRON Biotechnology INC, Sungnam, Republic of Korea). Collected lysates underwent Western blotting for SIRT1, SIRT3, and SIRT6. Antibodies against SIRTs were purchased from Abcam (Cambridge, UK). The quantification of the proteins was performed as described previously [5].

\section{Pan-SIRT activity assay and NAD+ assay}

Pan-SIRT activity was measured using a universal SIRT activity assay kit (CAT: ab156915, Abcam). Cells received 1, 10, and $100 \mu \mathrm{M} 4 \mathrm{HR}$, and cellular lysates were collected after 2,8 , and $24 \mathrm{~h}$. The subsequent procedure was in accordance with the manufacturer's protocol. In brief, $50 \mu \mathrm{L}$ of diluted capture antibody was added to each well, and the plate was incubated for $60 \mathrm{~min}$. After washing 3 times, $50 \mu \mathrm{L}$ of diluted detection antibody was applied to each well, and the plate was incubated for $30 \mathrm{~min}$. Then, the well was washed 4 times. For signal detection, $100 \mu \mathrm{L}$ of developer solution was applied, and the plate was incubated for $5 \mathrm{~min}$. To stop the reaction, $100 \mu \mathrm{L}$ of stop solution was applied, and the absorbance was measured at $450 \mathrm{~nm}$. The SIRT activity $(\mathrm{OD} / \mathrm{min} /$ $\mathrm{mg}$ ) was calculated using the following formula. The protein amount is expressed in micrograms, and min signifies incubation time in minutes.

Universal SIRT Activity $=\left(\frac{\text { Sample OD-NNC OD }}{\text { ProteinAmount } \times \min }\right) \times 1000$

The NAD+ assay was performed with an NAD+/ NADH assay kit (CAT: ab65348, Abcam). Cells received 1,10 , and $100 \mu \mathrm{M} 4 \mathrm{HR}$, and cellular lysates were collected after 2, 8, and $24 \mathrm{~h}$. For NADH measurements, the samples were heated to $60{ }^{\circ} \mathrm{C}$ for $30 \mathrm{~min}$ to decompose NAD. For the measurement of total NAD+/NADH, the heating step was omitted. Then, the samples were cooled on ice. The reaction mix was added to the samples and incubated for $5 \mathrm{~min}$ at room temperature to convert NAD+ to NADH. NADH developer was added, and the plate was incubated for $1 \mathrm{~h}$ during reaction cycles. Using a microplate reader, the absorbance was measured multiple times during the $1-4 \mathrm{~h}$ incubation.

\section{Statistical analysis}

Numeric data were shown as average \pm standard deviation. Independent samples $t$ tests were used for the comparison of two independent groups. For the comparison of more than three independent groups, analysis of variance was used. For post hoc tests, Bonferroni's method was used. The statistically significant level was set as $p<0.05$.

\section{Results}

\section{HR increased SIRT3 and SIRT6 expression}

The difference in the relative expression level of SIRT1 among the groups was not statistically significant (Fig. 1a; $p>0.05$ ). However, a difference in the relative expression levels of SIRT3 and SIRT6 among the groups was statistically significant (Fig. 1a, b; $p<0.001$ ). In the post hoc test, the expression level of SIRT3 was significantly increased in the $100 \mu \mathrm{M} 4 \mathrm{HR}$ group compared to untreated control at $24 \mathrm{~h}$ after administration $(p<$ 0.001). The expression level of SIRT6 was significantly increased in the 1,10 , and $100 \mu \mathrm{M} 4 \mathrm{HR}$ groups compared to that of the untreated control at $24 \mathrm{~h}$ after administration ( $p=0.001$ for $1 \mu \mathrm{M} 4 \mathrm{HR}$ group and $<0.001$ for 10 and $100 \mu \mathrm{M} 4 \mathrm{HR}$ groups). In addition, it was significantly increased in the $100 \mu \mathrm{M} 4 \mathrm{HR}$ groups compared to the untreated control at $8 \mathrm{~h}$ after administration $(p<0.001)$.

\section{HR increased pan-SIRT activity and NAD+ level}

The difference in pan-SIRT activity among the groups was statistically significant (Fig. 2; $p<0.001$ ). In the post hoc test, pan-SIRT activity in the 10 and $100 \mu \mathrm{M} 4 \mathrm{HR}$ groups was significantly higher compared to that of the 

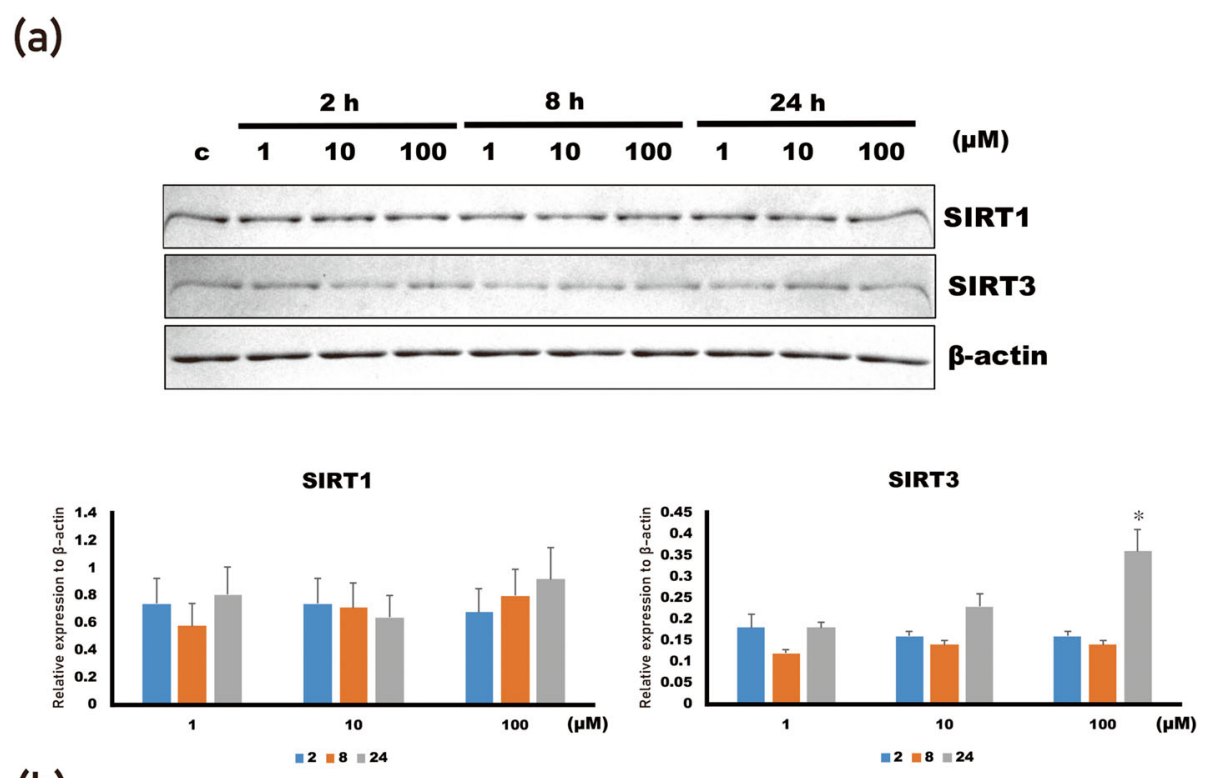

(b)

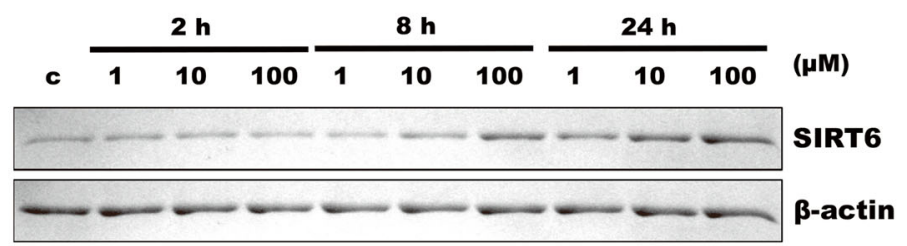

SIRT6

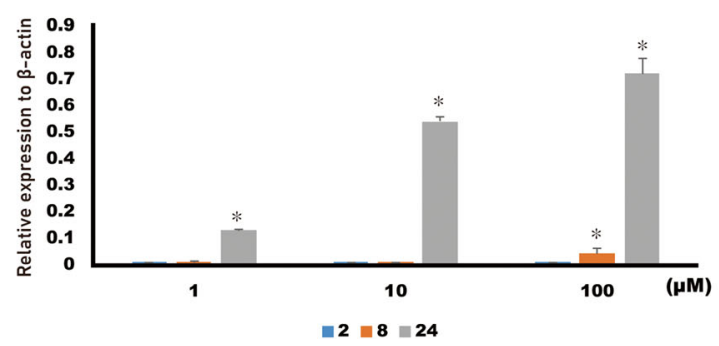

Fig. 1 Western blot for SIRT1, 3, and 6. a The expression level of SIRT1 was not significantly changed by 4HR administration (1-100 $\mu$ M). However, the expression level of SIRT3 was significantly increased in the $100 \mu \mathrm{M} 4 \mathrm{HR}$ group at $24 \mathrm{~h}$ after administration $\left({ }^{*} p<0.05\right)$. b The expression level of SIRT 6 was significantly increased in the $1-100 \mu \mathrm{M} 4 \mathrm{HR}$ group at $24 \mathrm{~h}$ after administration and in the $100 \mu \mathrm{M} 4 \mathrm{HR}$ group at $8 \mathrm{~h}$ after administration $\left({ }^{*} p<0.05\right)$

untreated control at $24 \mathrm{~h}$ after administration $(p=0.010$ and 0.001 , respectively).

The difference in NAD+ levels among groups was statistically significant (Fig. 3a; $p<0.001$ ). In the post hoc test, the NAD+ level in the 1, 10, and $100 \mu \mathrm{M} 4 \mathrm{HR}$ groups was significantly higher compared to that of the untreated control at $24 \mathrm{~h}$ after administration $(p<$ 0.001). Additionally, the NAD+ level in the $10 \mu \mathrm{M} 4 \mathrm{HR}$ groups was significantly higher compared to that of the untreated control at $8 \mathrm{~h}$ after administration $(p=0.003)$. The difference in NAD+/NADH ratio among the groups was statistically significant (Fig. 3b; $p<0.001$ ). In the post hoc test, the NAD+ level in the 1,10 , and $100 \mu \mathrm{M}$
$4 \mathrm{HR}$ groups was significantly higher compared to that of the untreated control at $24 \mathrm{~h}$ after administration $(p=$ 0.001 for $1 \mu \mathrm{M} 4 \mathrm{HR}$ group and $<0.001$ for 10 and 100 $\mu \mathrm{M} 4 \mathrm{HR}$ groups). Additionally, the NAD+ level in the $10 \mu \mathrm{M} 4 \mathrm{HR}$ groups was significantly higher compared to that of the untreated control at $8 \mathrm{~h}$ after administration $(p=0.034)$.

\section{Discussion}

Sirtuins are NAD+-dependent enzymes and are important for resistance to cellular stress. In this study, the expression of SIRT3 and 6 in Saos-2 cells was increased by 4HR administration $(1-100 \mu \mathrm{M}) \quad$ (Fig. 1). The 


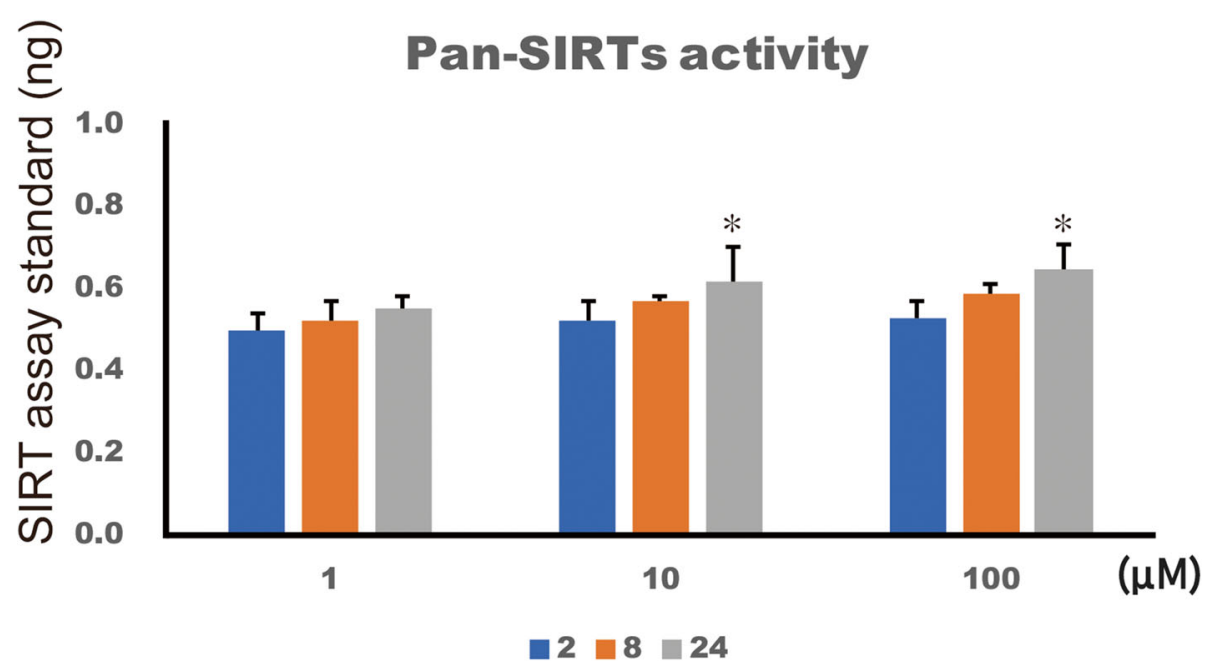

Fig. 2 Pan-SIRT activity. Pan-SIRT activity was significantly increased in the 10 and $100 \mu \mathrm{M} 4 \mathrm{HR}$ groups at $24 \mathrm{~h}$ after administration compared to that of the untreated control $\left({ }^{*} p<0.05\right)$

administration of 4HR increased pan-SIRT activity (Fig. 2). Additionally, the NAD+ level and NAD+ to NADH ratio were also in-creased by $4 \mathrm{HR}$ administration (Fig. $3)$. In conclusion, the administration of $4 \mathrm{HR}$ on Saos-2 cells showed increased SIRT3 and 6 expressions and pan-SIRT activity via an in-creased NAD+ to NADH ratio.

Prototype SIRTs are found in yeast, and their expression is associated with extension of the lifespan [13]. When the cellular metabolism is restricted, the expression level of SIRT1 is increased in the muscles [14]. SIRT3 is mainly expressed in mitochondria and associated with energy metabolism [15]. SIRT6 inhibits glucose uptake and its metabolism [16]. In this study, the administration of 4HR increased SIRT3 and SIRT6 in
Saos-2 cells (Fig. 1). According to our recent study, 4HR administration reduced mitochondrial respiratory activity and ATP synthesis in human umbilical vein endothelial cells (HUVECs) [17]. Therefore, 4HR-mediated inhibition of mitochondrial activity might be associated with increased SIRT3 and SIRT6 expression.

Reduced mitochondrial activity by $4 \mathrm{HR}$ administration might be fatal to cancer cells. Indeed, $4 \mathrm{HR}$ administration has been shown to have anti-cancer activity [18, 19]. Though the administration of $4 \mathrm{HR}$ would inhibit the growth of tumor, elevated SIRT3 and SIRT6 could play a protective role for cancer cells that survived after 4HR treatment, and these cancer cells might be more resistant to other cytotoxic cancer therapy. Superoxide dismutase (SOD) is activated by $4 \mathrm{HR}$ administration in (a)

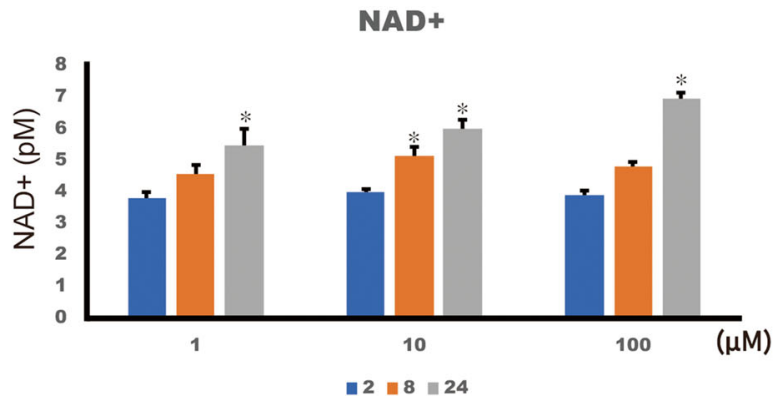

(b)

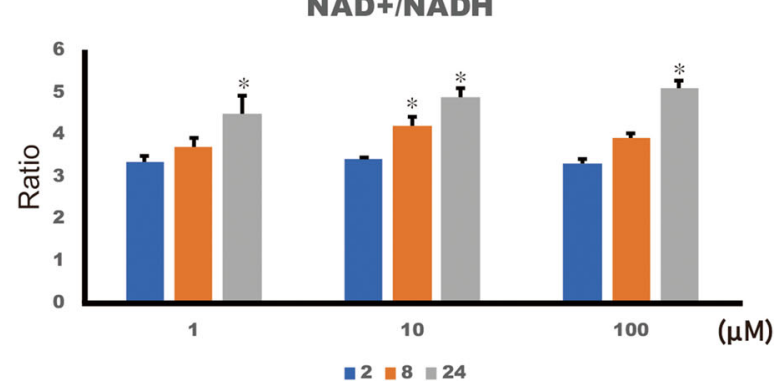

Fig. 3 NAD+ level. a The NAD+ level was significantly increased in the 1, 10, and $100 \mu \mathrm{M} 4 \mathrm{HR}$ groups at $24 \mathrm{~h}$ after administration compared to that of the untreated control $\left.{ }^{*} p<0.05\right)$. Additionally, it was significantly increased in the $10 \mu \mathrm{M} 4 \mathrm{HR}$ groups at $8 \mathrm{~h}$ after administration compared to untreated control $\left({ }^{*} p<0.05\right)$. b The NAD+/NADH ratio was significantly increased in the 1, 10, and $100 \mu \mathrm{M} 4 \mathrm{HR}$ groups at $24 \mathrm{~h}$ after administration compared to that of the untreated control $\left(^{*} p<0.05\right)$. Additionally, it was significantly increased in the $10 \mu \mathrm{M} 4 \mathrm{HR}$ groups at $8 \mathrm{~h}$ after administration compared to untreated control $\left({ }^{*} p<0.05\right)$ 
RAW264.7 cells [5]. SOD is also activated by SIRT3 activation [20].

Interestingly, 4HR administration increased the SIRT3 expression level (Fig. 1a). SIRT6 reduces pancreatic inflammation and fatty liver formation induced by a highfat diet [21]. SIRT6 decreases aging-associated inflammatory reactions via inhibiting the nuclear factor kappa B (NF-kB) pathway [22]. 4HR administration increased the SIRT6 expression level in this study (Fig. 1b), and $4 \mathrm{HR}$ is strong inhibitor of the NF-kB path-way $[23,24]$. The administration of $4 \mathrm{HR}$ decreases the expression of NF- $\kappa B$, while increases ikappaB kinase in HUVECs [25].

The level of NAD+ is associated with cellular stress. When the available nutrients are restricted, AMPactivated protein kinase (AMPK) is activated, and the NAD+ level is in-creased as a consequence [26]. Fibroblast growth factor 21 administration activates SIRT1 and reduces body weight [27]. The activity of SIRTs can be regulated by the NAD+ level [28]. In addition to SIRTs, poly(ADP-ribose) polymerases (PARPs) and cyclic ADP-ribose synthases also use NAD+ as an enzyme substrate $[9,11]$. As PARPs are DNA repair enzymes and highly expressed in cancer, their inhibitor can be used in cancer treatment [29]. PARPs are the main consumers of NAD+, and their inhibition may result in SIRT activation via flooding NAD+. However, the relation between PARPs and 4HR administration is yet to be clarified. In this study, 4HR administration increased the $\mathrm{NAD}+$ level and NAD+/NADH ratio (Fig. 3).

4HR has been developed as an antiseptic [30]. As the derivatives of resorcinolic lipid suppress microbial proliferation, the application of $4 \mathrm{HR}$ can inhibit microbial growth [8]. When $4 \mathrm{HR}$ is prescribed for oral intake, its absorption rate from the gastro-intestinal tract is poor [31]. When people receive $4 \mathrm{HR}$ per os, only $18 \%$ of the initial dosage is found in the urine within the first $12 \mathrm{~h}$ [31]. Due to the poor absorption rate, it has been prescribed for killing intestinal pathogens [32]. Russian scientists found that micro-organism surviving $4 \mathrm{HR}$ administration undergo dormancy and are more resistant to outer environmental stress [12]. Therefore, 4HR has been considered as a chemical chaperone. A 4HRmediated increase in SIRT activity and NAD+ level might be associated with its chaperone-like activity.

The possible anti-oxidant activity of $4 \mathrm{HR}$ might suggest that its applications can be useful in various conditions from orthodontic and surgical treatments. These conditions include gingivitis [33], root resorption [3], and dental pulp necrosis [6] during orthodontic treatment and several studies have reported that anti-oxidant activity can affect the expression of their manifestation $[4,5]$. The application of $4 \mathrm{HR}$ ointment accelerates diabetic burn wound healing via improved capillary regeneration [34]. Especially, the fact that $4 \mathrm{HR}$ has been proven to be safe as food additive for a long period [31] may make its utilization more promising.

A limitation of current study was that there are seven analogues of mammalian SIRTs. However, only SIRT1, 3 , and 6 expression levels were evaluated after $4 \mathrm{HR}$ administration. The expression levels of SIRT2, 4, 5, and 7 should also be evaluated. According to our recent study on HUVECs, SIRT2, 4, 5, and 7 mRNA levels were increased by $4 \mathrm{HR}$ administration in HUVECs [17]. In this study, pan-SIRT activity was increased by $4 \mathrm{HR}$ administration (Fig. 2). As individual SIRTs' activity might be different after 4HR administration, individual enzyme activity after $4 \mathrm{HR}$ administration should also be studied in following projects. In this study, Saos- 2 cell was used for evaluation. Saos-2 cell is originated from osteosarcoma cell and has been used for human osteoblastic cell [35]. As it was cancer cell, additional cellular experiment using primary cultured human cell would be required for the confirmation of current finding.

\section{Conclusion}

In this study, the administration of $4 \mathrm{HR}$ on Saos-2 cells increased the NAD+ level and NAD+/NADH ratio. The expression of SIRT3 and SIRT6 was also increased by 4HR administration.

\section{Abbreviations}

4HR: 4-hexylresorcinol; ROS: Reactive oxygen species; SIRT: Sirtuin; NFKB: Nuclear factor-kappa B; HUVECs: Human umbilical vein endothelial cells; NAD: Nicotinamide adenine dinucleotide

\section{Acknowledgements}

None.

Authors' contributions

LIS and CJH collected the data and wrote the manuscript. KDW performed cellular experiment. KSG and KTW revised original manuscript and edited figures. KTW did critical review. All authors read and approved the final manuscript.

\section{Funding}

This study was carried out with the support of the "Cooperative Research Program for Agriculture Science and Technology Development (Project no. PJ01562601)" Rural Development Administration, Republic of Korea.

\section{Availability of data and materials}

Data sharing is not applicable to this article since no dataset was generated or analyzed during the current study.

\section{Declarations}

Ethics approval and consent to participate

Not applicable.

Consent for publication

Not applicable.

Competing interests

The authors declare that they have no competing interests. KSG is an editorial board member of "Maxillofacial Plastic and Reconstructive Surgery." 


\section{Author details}

'Department of Orthodontics, School of Dentistry, Seoul National University, Seoul 3080, Republic of Korea. ${ }^{2}$ Department of Oral Biochemistry, College of Dentistry, Gangneung-Wonju National University, Jibyun-dong, Gangneung, Gangwondo 28644, Republic of Korea. ${ }^{3}$ Department of Oral and Maxillofacial Surgery, College of Dentistry, Gangneung-Wonju National University, Jibyun-dong, Gangneung, Gangwondo 28644, Republic of Korea.

\section{Received: 22 September 2021 Accepted: 12 October 2021}

Published online: 01 November 2021

\section{References}

1. Kim MJ, Yun PY, Chang NH, Kim YK (2020) The long-term evaluation of the prognosis of implants with acid-etched surfaces sandblasted with alumina: a retrospective clinical study. Maxillofac. Plast. Reconstr. Surg. 42(1):10. https://doi.org/10.1186/s40902-020-00255-6

2. Kwon TG, Han MD (2019) Current status of surgery first approach (part II): precautions and complications. Maxillofac. Plast. Reconstr. Surg. 41(1):23. https://doi.org/10.1186/s40902-019-0206-4

3. Jang JK, Kim DW, Kim SG, Kim TW (2020) Inhibitory effects of 4hexylresorcinol on root resorption induced by orthodontic tooth movement. Appl. Sci. 10(18):6313. https://doi.org/10.3390/app10186313

4. Yen GC, Duh PD, Lin CW (2003) Effects of resveratrol and 4-hexylresorcinol on hydrogen peroxide-induced oxidative DNA damage in human lymphocytes. Free Radic. Res. 37(5):509-514. https://doi.org/10.1080/1071 576031000083099

5. Jo YY, Kim DW, Choi JY, Kim SG (2019) 4-Hexylresorcinol and silk sericin increase the expression of vascular endothelial growth factor via different pathways. Sci. Rep. 9(1):3448. https://doi.org/10.1038/s41598-019-40027-5

6. Chang JH, Kim DW, Kim SG, Kim TW (2021) Alleviation of oxidative stress in dental pulp cells following 4-hexylresorcinol administration in a rat model. Appl. Sci. 11(8):3637. https://doi.org/10.3390/app11083637

7. López-Gómez L, Szymaszkiewicz A, Zielińska M, Abalo R (2021) Nutraceuticals and enteric glial cells. Molecules 26(12):3762. https://doi.org/1 0.3390/molecules26123762

8. Kozubek A, Tyman JHP (1999) Resorcinolic lipids, the natural non-isoprenoid phenolic amphiphiles and their biological activity. Chem. Rev. 99(1):1-26. https://doi.org/10.1021/cr9704640

9. Yang Y, Sauve AA (2016) Biochemistry and enzymology of sirtuins. In Sirtuins, Proteins and Cell Regulation; Houtkooper, R.H., Ed.; Springer: Heidelberg, Germany, pp. 1-28, ISBN 978-94-024-0961-1.

10. Michishita E, Park JY, Burneskis JM, Barrett JC, Horikawa I (2005) Evolutionarily conserved and nonconserved cellular localizations and functions of human SIRT proteins. Mol. Biol. Cell 16(10):4623-4635. https:// doi.org/10.1091/mbc.e05-01-0033

11. Cantó C, Boutant M (2016) SIRT1 in metabolic health and disease. In Sirtuins, Proteins and Cell Regulation; Houtkooper, R.H., Ed.; Springer: Heidelberg, Germany, pp. 71-104, ISBN 978-94-024-0961-1.

12. Kushneruk MA, Tugarova AV, II'chukova AV, Slavkina EA, Starichkova NI, Bogatyrev VA, Antoniuk LP (2013) Factors inducing transition from growth to dormancy in rhizobacteria Azospirillum brasilense. Mikrobiologiia 82(5): 563-570. https://doi.org/10.1134/S0026261713050081

13. Howitz KT, Bitterman KJ, Cohen HY, Lamming DW, Lavu S, Wood JG, Zipkin RE, Chung P, Kisielewski A, Zhang LL, Scherer B, Sinclair DA (2003) Small molecule activators of sirtuins extend Saccharomyces cerevisiae lifespan. Nature 425(6954):191-196. https://doi.org/10.1038/nature01960

14. Civitarese AE, Carling S, Heilbronn LK, Hulver MH, Ukropcova B, Deutsch WA, Smith SR, Ravussin E, CALERIE Pennington Team (2007) Calorie restriction increases muscle mitochondrial biogenesis in healthy humans. PLoS Med. 4(3):e76. https://doi.org/10.1371/journal.pmed.0040076

15. Kincaid B, Bossy-Wetzel E (2013) Forever young: SIRT3 a shield against mitochondrial meltdown, aging, and neurodegeneration. Front. Aging Neurosci. 5:48. https://doi.org/10.3389/fnagi.2013.00048

16. Zhang P, Tu B, Wang H, Cao Z, Tang M, Zhang C, Gu B, Li Z, Wang L, Yang Y, Zhao Y, Wang H, Luo J, Deng CX, Gao B, Roeder RG, Zhu WG (2014) Tumor suppressor p53 cooperates with SIRT6 to regulate gluconeogenesis by promoting FoxO1 nuclear exclusion. Proc. Natl. Acad. Sci. USA 111(29): 10684-10689. https://doi.org/10.1073/pnas.1411026111

17. Kim JY, Jo YY, Kweon HY, Kim DW, Lee SK Che $X$ et al (2021) Increased expression of TGF- $\beta 1$ by 4 -hexylresorcinol was due to the upregulation of mitochondrial stress and sirtuin activity in human endothelial cells. Appl. Sci. 11(19):9128. https://doi.org/10.3390/app11199128

18. Kim SG, Choi JY (2013) 4-hexylresorcinol exerts antitumor effects via suppression of calcium oscillation and its antitumor effects are inhibited by calcium channel blockers. Oncol. Rep. 29(5):1835-1840. https://doi.org/10.3 892/or.2013.2292

19. Lee SW, Kim SG, Park YW, Kweon H, Kim JY, Rotaru H (2013) Cisplatin and 4hexylresorcinol synergise to decrease metastasis and increase survival rate in an oral mucosal melanoma xenograft model: A preliminary study. Tumour Biol. 34(3):1595-1603. https://doi.org/10.1007/s13277-013-0690-6

20. Chen Y, Zhang J, Lin Y, Lei Q, Guan KL, Zhao S, Xiong Y (2011) Tumour suppressor SIRT3 deacetylates and activates manganese superoxide dismutase to scavenge ROS. EMBO Rep. 12(6):534-541. https://doi.org/10.1 038/embor.2011.65

21. Kanfi Y, Peshti V, Gil R, Naiman S, Nahum L, Levin E (2010) SIRT6 protects against pathological damage caused by diet-induced obesity. Aging Cell 9(2):162-173. https://doi.org/10.1111/j.1474-9726.2009.00544.x

22. Kawahara TL, Rapicavoli NA, Wu AR, Qu K, Quake SR, Chang HY (2011) Dynamic chromatin localization of Sirt6 shapes stress- and aging-related transcriptional networks. PLoS Genet. 7(6):e1002153. https://doi.org/10.1371/ journal.pgen.1002153

23. Song JY, Kim SG, Park NR, Choi JY (2018) Porcine bone incorporated with 4hexylresorcinol increases new bone formation by suppression of the nuclear factor kappa B signaling pathway. J. Craniofac. Surg. 29(7):19831990. https://doi.org/10.1097/SCS.0000000000004517

24. Kim YS, Kim DW, Kim SG, Lee SK (2020) 4-hexylresorcinol-induced protein expression changes in human umbilical cord vein endothelial cells as determined by immunoprecipitation high-performance liquid chromatography. PLoS ONE 15(12):e0243975. https://doi.org/10.1371/journal. pone.0243975

25. Kim MK, Kim SG, Lee SK (2020) 4-Hexylresorcinol-induced angiogenesis potential in human endothelial cells. Maxillofac. Plast. Reconstr. Surg. 42(1): 23. https://doi.org/10.1186/s40902-020-00267-2

26. Canto C, Jiang LQ, Deshmukh AS, Mataki C, Coste A, Lagouge M et al (2010) Interdependence of AMPK and SIRT1 for metabolic adaptation to fasting and exercise in skeletal muscle. Cell Metab. 11(3):213-219. https://doi.org/1 0.1016/j.cmet.2010.02.006

27. Chau MD, Gao J, Yang Q, Wu Z, Gromada J (2010) Fibroblast growth factor 21 regulates energy metabolism by activating the AMPK-SIRT1-PGC-1alpha pathway. Proc. Natl. Acad. Sci. USA 107(28):12553-12558. https://doi.org/10.1 073/pnas.1006962107

28. Rogina B, Helfand SL (2004) Sir2 mediates longevity in the fly through a pathway related to calorie restriction. Proc. Natl. Acad. Sci. USA 101(45): 15998-16003. https://doi.org/10.1073/pnas.0404184101

29. Curtin NJ, Szabo C (2013) Therapeutic applications of PARP inhibitors: Anticancer therapy and beyond. Mol. Asp. Med. 34(6):1217-1256. https://doi. org/10.1016/j.mam.2013.01.006

30. Leonard V (1925) The significance of hexylresorcinol and its homologues in relation to the problem of internal antisepsis. Science 62(1610):408-412. https://doi.org/10.1126/science.62.1610.408

31. PubChem. Available online: https://pubchem.ncbi.nlm.nih.gov/compound/3 610 (accessed on 25 July 2021)

32. Jung RC (1954) Use of a hexylresorcinol tablet in the enema treatment of whipworm infection. Am. J. Trop. Med. Hyg. 3(5):918-921. https://doi.org/1 0.4269/ajtmh.1954.3.918

33. Martin BJ, Campbell PM, Rees TD, Buschang PH (2016) A randomized controlled trial evaluating antioxidant-essential oil gel as a treatment for gingivitis in orthodontic patients. Angle Orthod. 86(3):407-412. https://doi org/10.2319/041515-251.1

34. Kim DW, Jo YY, Garagiola U, Choi JY, Kang YJ, Oh JH, Kim SG (2020) Increased level of vascular endothelial growth factors by 4-hexylresorcinol is mediated by transforming growth factor- $\beta 1$ and accelerates capillary regeneration in the burns in diabetic animals. Int. J. Mol. Sci. 21(10):3473. https://doi.org/10.3390/ijms21103473

35. Hausser HJ, Brenner RE (2005) Phenotypic instability of Saos-2 cells in longterm culture. Biochem. Biophys. Res. Commun. 333(1):216-222. https://doi. org/10.1016/j.bbrc.2005.05.097

\section{Publisher's Note}

Springer Nature remains neutral with regard to jurisdictional claims in published maps and institutional affiliations. 